\title{
Public Accounting as a profession in Mexico
}

\section{La Contaduría Pública como Profesión en México}

\author{
PAREDES-BARRÓN, Adriana†*, SILVA-CONTRERAS, Juan and ANDRADE-OSEGUERA, Miguel \\ Angél
}

Universidad Tecnológica del Suroeste de Guanajuato

ID $1^{\text {st }}$ Author: Adriana, Paredes-Barrón / Researcher ID Thomson: S-6458-2018, arXiv Author ID: 73Y8LW-F8GQZB, CVU CONACYT ID: 947184

ID $1^{\text {st }}$ Coauthor: Juan, Silva-Contreras / ORC ID: 000-0003-1913-9910, arXiv Author ID: LAJ9UT-QHDDL4, CVU CONACYT ID: 509502

ID $2^{\text {nd }}$ Coauthor: Miguel Angél, Andrade-Oseguera/ ORC ID: 0000-0002-7926-9162, Researcher ID Thomson: S-65862018, CVU CONACYT ID: 509502

DOI: $10.35429 / J A F .2019 .18 .6 .17 .21$

Recibido March 20, 2019; June 30, 2019

\begin{abstract}
Every profession has a function of responsibility to society, which implies dedication, compliance and permanent updating, credibility and, above all, appropriating their ideals, making them part of their being, with certain ideas, ethical compliance, values and practices that characterize him as a professional. Exercising the profession of Public Accountant implies a sense of social responsibility, of acting with integrity of values and ethics, if one takes into account that society demands such compliance, in addition to a behavior of honesty and certainty. In Mexico, the Public Accountant has different areas of specialization in which professionals can find work cavity today. The main objective of this article is to analyze and identify the functions of a future professional in Public Accounting as well as the work areas to be carried out.The background, essential characteristics, challenges and fields of action of the profession in Mexico are included, thus contributing to the election of career for university futures.
\end{abstract}

Responsibility, Ethics, Honesty and Certainty

\begin{abstract}
Resumen
Toda profesión tiene una función de responsabilidad ante la sociedad, la cual implica dedicación, cumplimiento y actualización permanente, credibilidad $\mathrm{y}$, sobre todo, apropiarse de sus ideales, haciendo que estos sean parte de su ser, con ideas ciertas, de cumplimiento ético, de valores y prácticas que lo caractericen como profesional. Ejercer la profesión de Contador Público conlleva un sentido de responsabilidad social, de actuación con integridad de valores y de ética, si se tiene en cuenta que la sociedad exige dicho cumplimiento, además de un comportamiento de honestidad y certidumbre. En México, la Contaduría Pública tiene diferentes áreas de especialización en la que hoy los profesionales pueden encontrar cavidad laboral. El principal objetivo de este artículo es analizar e identificar las funciones de un futuro profesionista en Contaduría Pública así como las áreas laborales a desempeñar. Se incluyen antecedentes, características esenciales, retos y campos de actuación de la profesión en México contribuyendo así en la elección de carrera para futuros universitarios.
\end{abstract}

Responsabilidad, Ético, Honestidad y Certidumbre

Citation: PAREDES-BARRÓN, Adriana, SILVA-CONTRERAS, Juan and ANDRADE-OSEGUERA, Miguel Angél. Public Accounting as a profession in Mexico. Journal of Administration and Finance. 2019, 6-18: 17-21

$\dagger$ Researcher contributing first author. 


\section{Introduction}

Since ancient times it has been the need of any society to obtain information from the surrounding environment. In a company, it is necessary to have information that serves to make decisions as well as to comply with fiscal obligations. This information is provided by the accounting. The social need that satisfies this profession is the universal and constant requirement that people and financial information entities have to make decisions and comply with fiscal obligations.

The history of Public Accounting in Mexico begins on May 25, 1907, when Mr. Fernando Diez Barroso receives the first title of Accountant of Commerce that is issued in Mexico, and who years later proposes changes to the curricula, so that the title granted changes to Public Accountant. Since then, there have been several generations of young people who have found in this profession the ideal space to develop and contribute to the country's progress, whose history is not conceived without the numerous contributions of women and men, who have dedicated themselves to cultivating this discipline and Teach it in university classrooms.

In Mexico, the Public Accountant has different areas of specialization in which professionals can find work cavity today. The Public Accountant is not only dedicated to the position and payment, but is also dedicated to the Fiscal, Audit, Costs, Finance and Administration part as good successful entrepreneurs in the Companies.

\section{Justification}

The purpose of this article is to expand knowledge about the characteristics, qualities and functions of the areas in which the future Public Accounting professional can perform.

\section{Problem}

The fear of being replaced by technology caused a drop in enrollment in this profession: in 2016 722,466 people were registered. However, for the following year, the figure rose to 735,611 professionals, according to data from the Labor Observatory.

\section{Hypothesis}

In Mexico, accounting is one of the most requested and indispensable professions within an organization. Accountants will remain relevant as long as people and businesses exist.

\section{Objevtives}

\section{General objective}

Analyze and identify the functions of a future Public Accounting professional as well as the work areas to perform.

\section{Specific objectives}

- Define the characteristics of Public Accounting in Mexico.

Identify the needs it meets.

- Determine the fields of action and sectors it serves.

\section{Theoretical framework}

\section{What is a profession?}

Profession, from the Latin professio, is the action and effect of professing (exercising a trade, a science or an art). The profession, therefore, is the employment or work that someone exercises and for which he receives an economic compensation. (Definition of profession, what it is, meaning and concept, 2019)

\section{Essential characteristics of every profession}

- Specialized preparation. Every profession implies a humanistic, scientific, specialized and qualified preparation that must be reflected in the theoretical and specialized knowledge.

- $\quad$ Service to others. The professional puts his knowledge and skills at the service of those who need that competence in exchange for recognition.

- Economic Renumbering The exercise of a profession brings a reward, this is economical that will allow the subsistence of the professional.

- Loyalty. It is the fidelity with himself and the users that must be manifested in the execution of actions inherent to his profession. 
- Spirit of self-denial. The professional must worry about providing a good service taking care of human, economic and natural resources.

- Tolerance practice. The professional should not make absurd distinctions of nationality, race, sex, religion, color, political opinion or social status because all users deserve respect.

- Empathy. Consider colleagues with the same rights and duties as himself to understand emotions, feelings and expectations.

- Objectivity in the acts. You must see reality with objectivity and understand that reality has objective character.

\section{Accounting Profession in Mexico}

\section{Definition}

The Public Accountant is understood as the natural person who, by means of the registration that proves his professional competence in the terms of this, is empowered to give public evidence of facts specific to the scope of his profession, to rule on financial statements and to carry out the other activities related to Accounting science in general. (The Public Accounting, 2006)

\section{Public Accounting Requirements as a profession}

Academics The professional must take a baccalaureate, vocational or equivalent; approve the subjects of the corresponding curriculum; cover the corresponding social service and obtain a professional title and certificate once the professional exam is passed.

- Legal To exercise this profession requires a professional degree with official validity. Social. In order to make decisions, society needs reliable financial control and information of the economic entities and to promote it is the function of a Public Accountant.

- Personal and intellectual. The professional requires logical reasoning skills to solve accounting and financial problems as well as making accurate decisions as well as possessing human quality, good customs and honesty. (The Public Accounting, 2006)

\section{Background}

In Mexico, when the Spanish conquerors arrived in the Valley of Mexico, the country was divided into several independent kingdoms, the Aztec people standing out for their dynamism, discipline and cruelty. In the Great Tenochtitlan there was a large market of goods and, logically, there was accounting practice (until now little explored), legal regulations, order and discipline in trade practices.

Soon, these practices were replaced by the uses and customs of the Spaniards. In public order, the practice of Accounting was similar to that carried out in Spain, under the Ordinances of Burgos and Bilbao, of 1494 and 1538, which were applied in Mexico for more than 300 years.

Accounting was learned in commercial establishments, only until 1845 are the Commercial Schools founded; in the "Commercial Institute" the commercial uses were learned in rules related to trade. The effort of these professions was crowned with a diplo $\neg$ ma of "Bookkeeper", later of "Accountant of Commerce”.

When Mexico made its Political Independence from Spain, at the beginning of the 19th century, the country was fundamentally agricultural, livestock, mining and commercial. Sugar farming in "trapi-ches", and mining were the only ones that used specialized machinery and labor in an incipient way.

The beginning of a manufacturing industry began to grow in the last third of the nineteenth century. Hence the Mexican Stock Exchange was founded in 1894, almost when the new century arrived, when Mexico was already an incipiently industrial country, in which the accounting technique and the profession of Commerce Accountant, which was then Public, gave foot in 1906 the foreign office of Price Water House was founded in the country. The companies that were listed on the Exchange needed, since always, the support of financial statements signed by Independent Public Accountants.

In 1917 the Mexican Institute of Public Accountants was created, whose founding members were distinguished professionals. 
In 1921, the Centennial Law was promulgated - from the Income Tax -; That same year, the Bank of Mexico was founded, the governing body issuing the currency. Porfirio Díaz received power with only one railroad: Veracruz-Mexico, in 1877; at the end of his government, there were 19 thousand kilometers of railways.

Fernando Diez Barroso - who was born in 1887 and died in October 1930 - had to live that Mexico that managed to transform Porfirio Díaz, during more than 30 years of government, where there was "Law and Order". Ten Barroso was born in an agricultural country and lived the road to industrialization. He and his generation were exemplary nationalists and generous citizens in their public life, that is, committed to the country.

Fernando Diez Barroso was the first to receive the title of Public Accountant. In his person is the symbol of a modern accounting profession that contributed significantly to forging the country in which we live today. (IMCP.ORG.MX, s.f.)

\section{Accounting Challenges in Mexico}

The great dynamics of today's world requires that any career be constantly updated and different challenges arise that are met by its actors. Counter Resa considers that within the series of challenges facing the Accounting is learning to anticipate, as much as possible, in the way of doing business and the problems that the growth of them. "You must be aware that there are increasing risks in terms of services that lend themselves to society, that is, every day more trust is entrusted at the counter as a financial guide, which will demand in subsequent years moral quality and preparation".

For the above -he points out-, educational institutions must be ready to develop curricula that contribute to forge more effective counters, who not only have knowledge, but also values. "This is what makes the difference in a service, the core values".

The great challenge is the constant update, because with the global competition between companies, to achieve better market positions and shares, more professionals are required.
You have to be in constant innovation and remember that financial challenges translate into challenges for the accountant, "concludes Don Manuel Resa García. (IMCP.ORG.MX, s.f.)

\section{Fields of action served by a graduate in public accounting}

\section{Fiscal}

In essence, the main job of the accountant is to support the taxpayer to fulfill his obligations before the treasury; that is to say, he is in many occasions the one in charge of carrying out all the paperwork, from the opening and discharge in hacienda to the liquidation, to determine the contributions and to promote the good fiscal practices, for the fiscal accountant life is not easy, he has to deal with with the authorities (IMSS, State Finance, SAT, INFONAVIT, etc.) and also deal with their clients.

\section{General counter}

He is in charge of keeping the accounting books of a company, obviously, the general accountant has to be very complete, because among his responsibilities is, verify that the company is financially sound, be aware of compliance with tax obligations, prepare financial statements and develop an internal control.

\section{Cost accountant}

The cost counter's job is to determine the cost of production; that is, determine how much it costs to make a product and from there determine its price.

In the words of Accountant Ruben Arceo López "I provide my services as a cost analyst for one of the best brands in clothing for national and transnational women, my main job is to propose the solution to inventory valuations contribute to dominate the production cost of the product finished, analyzing direct and indirect expenses for determining competitive prices to the public, analyzing and budgeting degrees of production, in this company we also work with the technologies of implementing physical inventory procedures with the help of systems such as ERP, SAP and GREAT PLAINS Microsoft also contribute and strengthen the work with my experience in Microsoft Office moving forward we work as a team to achieve our projects and work purposes. (López, 2015) 


\section{Auditor of Financial Statements}

$\mathrm{He}$ is in charge of reviewing the correct management of the accounting of a financial entity, it is up to him to validate that what his specialized colleagues in other areas have done is well done, his work is very important. When this work is done well, it can support correcting mistakes and amending unfavorable situations, when it is done badly or unethically. (The accountant's labor field, 2014)

\section{Manager}

In the content of the undergraduate programs of Public Accounting, in addition to the subjects of the career, some related to humanities, economics, statistics, calculation, administration and project management are generally included, which allow the accountant to adopt a role leader, identify opportunities in the market and serve as manager or administrator of different types of business. Additionally, for his technical knowledge in finance, control, costs and auditing, he is one step ahead to be selected in management positions.

\section{Teacher}

After having a mastery of the accounting exercise in everyday life, of the concepts and technical principles that frame the profession, and of aspects related to ethics and public faith, exercising as a teacher can be a work, as well as satisfactory, very enriching. It should be noted that, in order to be a good teacher, these conditions are not enough, a quota of discipline, vocation, innovation and pedagogy is also required. It is necessary for the public accountant to have a background in education, interpersonal relations and information technologies, if you wish to practice as a teacher.

\section{Investigator}

Due to the time that must be spent in consulting, consolidating, interpreting and applying the regulations issued by government entities every day for the exercise of the public accountant, training through articles, books, conferences, magazines, research papers, infographics, formats, among others, that serve to support this exercise, is well received by users.
That is why different publishing houses, universities and web portals contract with accounting professionals who have the ability to interpret and design different printed and digital products for accountants and taxpayers. The accounting professional who acts as a researcher must possess, in addition to the technical knowledge of the profession, skills to communicate assertively, write and discern what the user requires. (Areas where accountants can perform, 2018)

\section{Conclusions}

Today, the accountant's career has diversified in such a way that it is not enough just to have tax, accounting or financial knowledge. It should be clear that the function of the accountant is the correct operation at the financial level of a company; $\mathrm{He}$ is in charge of knowing all the financial information in detail, and in that sense it is essential that he knows how to correctly handle financial reasons, legal practices and thus be able to issue whether the company or organization is profitable or not.

There are currently thousands of companies that have the idea of "I think it will be fine", but the success of the companies not only lies in a simple hunch, it is necessary to be able to see with the numbers and not with the eyes and before that the accountant must Be quite skilled. The vocation is very necessary, and so it is that every public accountant is a primary resource of any company, although companies do not even know it.

\section{References}

IMCP.ORG.MX, Obtenido de wWw.imcp.org.mx

wWw.monografías.com.mx

(Areas en que pueden desempeñarse contadores, 2018)

(La Contaduría Pública, 2006) 